\title{
Quaternary Geology and Geomorphology of Terna River Basin in West Central India
}

\author{
Mohammad Babar, Radhakrishna Chunchekar, Madhusudan G. Yadava, Bhagwan Ghute
}

How to cite:

Babar, Md., Chunchekar, R.V., Yadava, M.G., Ghute, B.B. (2012): Quaternary Geology and Geomorphology of Terna River Basin in West Central India. - E\&G Quaternary Science Journal, 61 (2): 159-168. DOI: 10.3285/eg.61.2.04

Abstract:

This paper presents the morphostratigraphy, lithostratigraphy and sedimentary structures of Terna River basin in the Deccan Basaltic Province (DBP) of West Central India. These Quaternary deposits have been divided into three informal formations (i) dark grey silt formation - Late Holocene, (ii) Light grey silt formations - Early Holocene, (iii) Dark grayish brown silt formation - Late Pleistocene with the older Quaternary Alluvial deposits of Upper Pleistocene age. The fine clay and silt formations in the lower reaches reflect that the streams are of low gradient and more sinuous. The river shows evidences of channel movement by avulsion, largely controlled by lineaments. Palaeo-levees, in the form 4-5 m high ridges exist along the Terna River floodplain, specifically in the Ter, Killari, Sastur, Dhuta and Makni villages. Several lineaments occur along NE-SW, NW-SE, E-W and WNW-ESE directions, which control the basement structure in the study area. The values of the Topographic Sinuosity Index (TSI) indicate rejuvenation of the area leading to the dominance of topography on the sinuosity of the river channels. The break in slope in the long profile is also indication of the Quaternary tectonic uplift of the area. Radiocarbon dating of some charcoal fragments collected from folded beddings indicates that paleoseismic activity might have taken place along the basin between AD 120 and AD 1671 .

\section{Quartärgeologie und Geomorphologie des Terna Beckens im westlichen Zentralindien}

Kurzfassung:

\begin{abstract}
Im vorgelegten Artikel werden die Morphostratigraphie, Lithostratigraphie sowie die Sedimentstrukturen des Terna Beckens in der Deccan Basaltic Province (DBP) im westlichen Zentralindien vorgestellt. Die Quartärablagerungen können in drei große Einheiten unterteilt werden (i) dunkelgraue Schluffablagerungen - Spätes Holozän, (ii) hellgraue Schluffablagerungen - Frühes Holozän, (iii) dunkelgrau-braune Schluffablagerungen - Spätpleistozän mit altquartären alluvialen Absätzen mit oberpleistozänen Altern. Die feinen tonig-schluffigen Ablagerungen im Unterlauf des Flusses deuten auf ruhige Ablagerungsbedingungen und einen sinusartigen Abfluss hin. Der Fluss zeigt Tendenzen zu abschwemmungsbedingten Gerinneverlagerungen, die wiederum durch vorhandene Bruchlinien gesteuert wurden. Entlang des Terna-Flusses konnten weiterhin Paläouferrücken in Form von 4-5 m hohen Rücken nachgewiesen werden, hier vor allem im Bereich der OrtschaftenTer, Killari, Sastur, Dhuta und Makni. Einige nachgewiesene Bruchlinien treten vor allem in NE-SE, NW-SE, E-W und WNW-ESE-Richtung auf und bestimmen die Struktur des Grundgebirges im Untersuchungsgebiet. Die TSI-Werte (Topographic Sinousity Index) verdeutlichen einen Erosionswechsel im Untersuchungsgebiet mit einer Verstärkung des topographischen Einflusses auf die Ausformung der Abflussbahnen. Die im Profil sichtbare Geländekante zeugt weiterhin von einer tektonischen Hebung des Gebietes im Quartär. Radiokohlenstoffdatierungen, die an einigen Holzkohlefragmenten durchgeführt wurden, die aus gefalteten Ablagerungen entnommen wurden, deuten darauf hin, dass eine
\end{abstract} seismische Aktivität in der Zeitspanne zwischen 120-1671 n. Chr. stattgefunden haben kann.

Keywords: Quaternary Geology, Lithologs of Quaternary sediments, morphostratigraphy, Geomorphology, Terna River

Addresses of authors: Md. Babar ${ }^{1}$, R.V. Chunchekar ${ }^{1}$, M.G. Yadava ${ }^{2}$ and B.B. Ghute ${ }^{1}$ Department of Geology, Dnyanopasak College, Parbhani-431 401 (M.S.) India, ${ }^{2}$ Physical Research Laboratory, Ahmedabad-380 009, Gujrat India, E-mail: md-babar@hotmail.com

\section{Introduction}

The Peninsular India was considered to be tectonically stable, until the Killari-Latur earthquake in 1993 (Fig. 1), which was followed by another event at Jabalpur in 1997 (Fig. 1) and continued episodes of reservoir induced earthquakes at Koyna (Maharashtra India) since 1967 (Fig. 1). The epicenter of the devastating Killari-Latur earthquake $(\mathrm{mb}=6.3)$ of September 30, 1993 is located in the Terna drainage basin (Fig. 2). This event is one of the rare occurrences of an earthquake in shield area and brought into focus several unresolved ques- tions regarding the intracratonic earthquakes. The seismicity recorded in this region in the last few decades apparently contradicted the traditional notion of the tectonic stability of the Deccan Volcanic Province (DVP). These earthquakes also demonstrated the catastrophic effects and the risk of annihilating earthquakes occurring in the DVP in Peninsular India in response to ongoing neotectonic activity in the region. The observed seismicity has so far remained unexplained within a neotectonic framework in the absence of such studies in the region. No study has been attempted to so far on documentation of neotectonic evidences and its influence on 


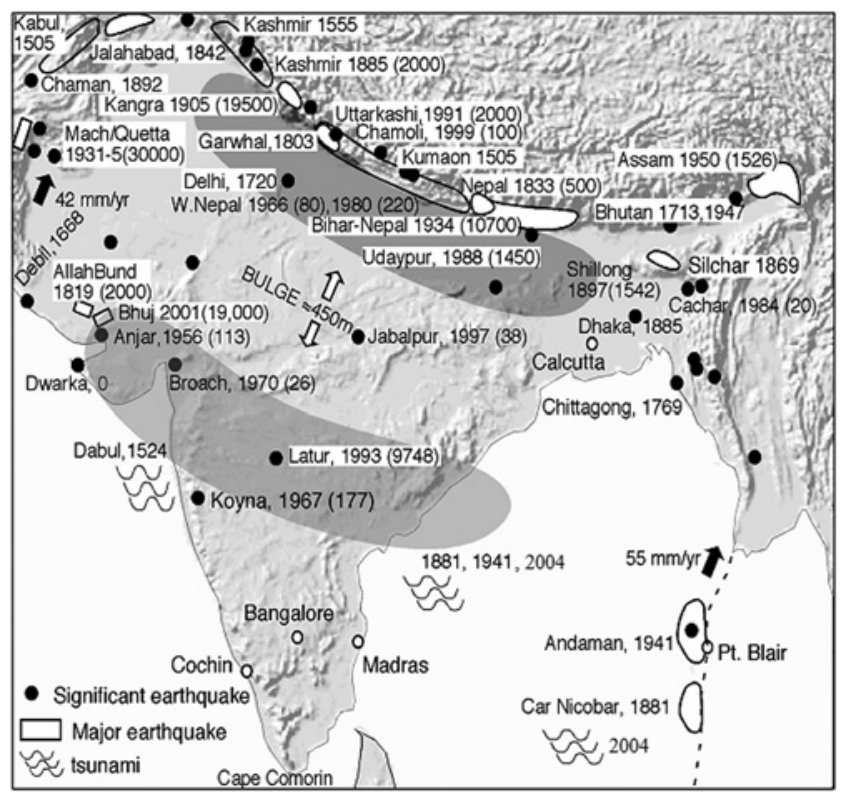

Fig 1. Schematic views of Indian Tectonics and historic Earthquakes map of India (Modified after Bilham 2004). The values in bracket indicate the number of casualties because of the earthquake. Shading indicates flexure of India: a $4 \mathrm{~km}$ deep trough near the Himalaya and an inferred minor (40 $m$ ) trough in south central India are separated by a bulge that rises approximately $450 \mathrm{~m}$

the shaping of the landscape in the recent geologic past. The Quaternary deposits occurring in the Terna basin have also remained uninvestigated so far, which are potential archives for delineating past neotectonic and seismic events and Late Quaternary evolutionary history.

The earthquake near Killari-Latur along Terna River demonstrated the need for detailed neotectonic reappraisal of the DVP, which consists primarily of a thick pile of trappean lava flows and narrow fringe of Quaternary sediments. Although, the lava flows have been studied extensively in terms of their petrological characteristics and geochemistry but studies on their structural aspects, geomorphological and neotectonic evolution are virtually sporadic. The alluvial deposits in western uplands of Maharashtra have been studied with respect to Neogene uplift of Peninsular India and Quaternary paleoclimatic changes (RADHAKRISHNA 1993; RAJAGURU et al. 1993; RAJAGURU \& KALE 1985). The studies carried out so far (BABAR et al. 2000) indicate a control of structure and neotectonics on the geomorphic set up and drainage configuration of the Terna basin. Lineament and fault controlled drainage pattern, entrenched meanders, incised cliffs of Quaternary sediments and bedrock and a rejuvenated topography points to a dominant control of neotectonic activity on the landscape evolution of the area.

The paper represents the Quaternary Geology and geomorphology of Terna River basin in the DVP of West central India. The location of sites is given in Fig. 2. The Quaternary geological mapping was carried out in the area in order to generate the data on morphostratigraphy and lithostratigraphy. The lineaments occurs along NE-SW, NW-SE, E-W and WNW-ESE directions (Fig. 3), which has influenced the drainage network of the area and the tributaries of the Terna River.

\section{Geology of the area}

Geologically, the entire study area belongs to DVP of Peninsular India (Fig. 4). Deccan volcanism is considered to be a manifestation of original tectonic regime developed within the continental lithospheric plate (CHANDRASEKHARAM 1985; Cox 1989; Cox 1991; Bose 1996). The stress conditions in the Indian peninsula initiated formation of fissure swarms and with increasing intensity and developed miniature Continental rifting. The Killari-Latur 1993 earthquake rejuvenated the debate over the existence of rift valleys underneath the DVP (VAldiYA 1993; KaILASAm 1993).

The Deccan Traps, which cover an area of more than $600,000 \mathrm{sq} \mathrm{km}$ of this region, consist of a number of flows ranging in thickness from a few meters up to about $100 \mathrm{~m}$ with the successive flows being separated by red bole or Inter-trappean beds and are characterized by compact basalt at the bottom part succeeded by a vesicular zone (GUPTA \& DwIVEDy 1996). The Deccan trap sequence, in general, is classified into stratigraphic units on the basis of chemical composition of various flows (e.g. Mitchell \& WidDOwson 1991). The southern part of Deccan volcanic province in the eastern Maharashtra is composed of Poladpur and Ambenali Formations of the Wai sub group (MITCHELl \& WIDDOWson 1991; BilgrAmi 1999).

The Deccan basalt flows, in general, are broadly horizontal in disposition and exhibits gentle gradients. The gradient is towards ENE and SE. Drilling at Killari (GuPTA \& DwIVEDY 1996; GuptA et al. 1998) indicates that the total thickness of basaltic layers is about $338 \mathrm{~m}$ with about 12-15 flows. The lava flows are underlained by $8 \mathrm{~m}$ thick infratrappean sequence comprising 1-2 $\mathrm{m}$ oxidized shale followed by a conglomeratic grit-sandstone. This layer overlies the Precambrian granitic basement (biotite-granitic gneisses to pink granite). In the present study area there are nine basaltic lava flows as given in Table 1.

Closely spaced gravity survey and modeling along the two profiles (MishrA et al. 1998) across the epicentral area of 1993 Killari-Latur earthquake suggest some high and low density bodies of shallow origin indicating highly heterogeneous basement. Under these circumstances the most convincing evidence of paleoseismicity as well as tectonic activity, which may have occurred in this region, is most likely to come from the sediments, which have been preserved along the rivers.

\section{Methodology \\ 3.1 Satellite Data}

For the present study the IRS P6 LISS III 2010 satellite data was used to delineate Quaternary litho units of the Terna River. Active channels and floodplain features were mapped. The digital data format from Indian remote sensing satellite (IRS P6) of LISS-III 2010 with 24 m spatial resolution with four spectral bands was used to meet the requirement of area under study. The image taken was false colour composite (FCC) on 1:50,000 scale, having band combination of 4:3:2:1 (NIR: red: green). The SOI toposheets and digital satellite data were geometrically rectified and geo-referenced and merged using Arc GIS 9.3. 


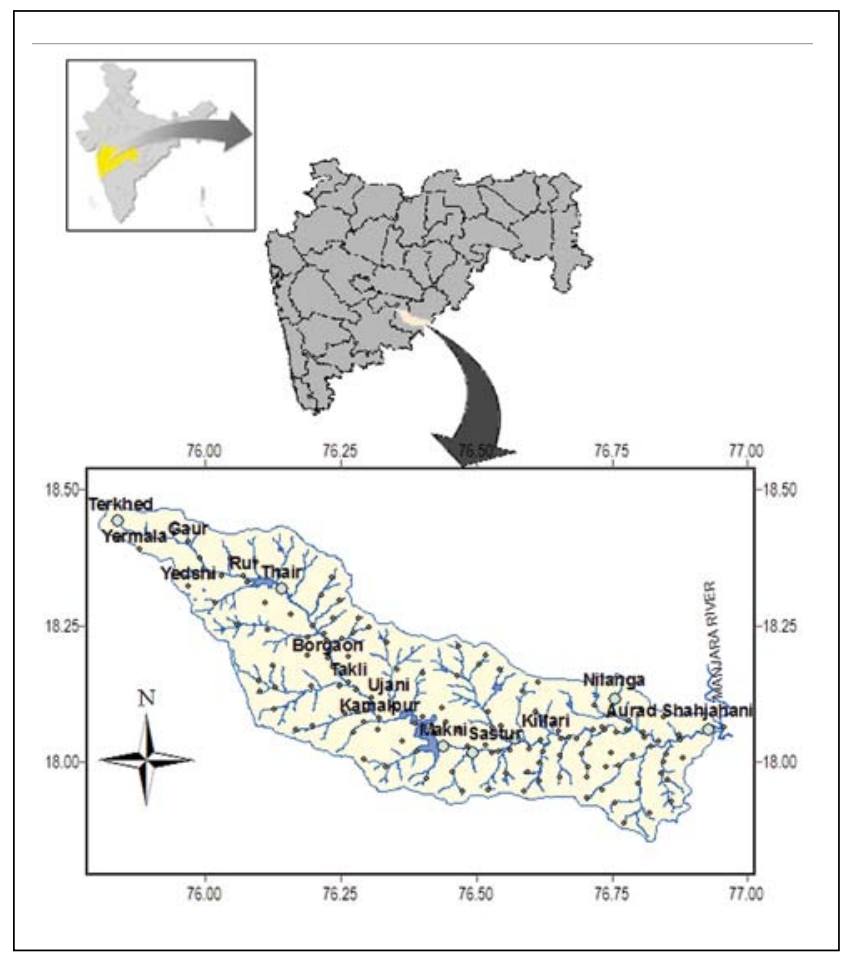

Fig. 2: Location map of study area for sites of lithologs along the Terna River Basin

\subsection{Field Work}

The geomorphic study carried out was based on the satellite data, Survey of India (SOI) topographic maps and extensive field survey. The height of terrace surfaces was determined using the data acquired through toposheets and hand-held global positioning systems (GPS). The data presented are based on the field observation on several outcrops, where a representative section has been discussed in detail. The morphological details are presented after careful examination of SOI topographic maps and observations made in the field. Sections were logged and sedimentary structures were de- scribed in the field itself. The fieldwork is under taken during 2009-10.

The river shows the evidences of channel movement by avulsion and the lineaments largely control these. Older palaeo-levees exist in the form of ridges $4-5 \mathrm{~m}$ high at Ter, Killari, Sastur and Makni villages along the Terna River floodplain. The abnormally greater thickness of sediments is recorded at Ter village, consisting of mounds of 12 to $15 \mathrm{~m}$ height from the bed level of the Terna River (RAJENDRAN et al. 1996; Suknija et al. 2006). In the field these are marked by a curvilinear deposition of Paleolithic sites on the silty or sandy over bank deposits. They occur as irregular patches and can be related to the older course of the river. Several lineaments run NE-SW, NW-SE, E-W and WNW-ESE directions (Fig. 3), which control the basement structure in the study area. The lineament map is prepared using the basin map prepared in Arc GIS 9.3 and the lineaments are incorporated from the lineament maps of ARYA et al. (1995) and SRIVASTAVA et al. (1997). The geology of area is illustrated in Fig. 4, litho-sections were logged (Fig. 5) and sedimentary structures were described.

\subsection{Radiocarbon Analysis}

For the present study seven charcoal samples were collected from different locations including two samples from Ter area, one each from Duta and Makhani and three samples from Killari villages locations, depth and ages with Figures referred are given in Table 4. Ages of charcoal fragments were estimated by radiocarbon dating method following liquid scintillation spectrometry (YADAVA \& RAMESH 1999). Benzene was synthesized from sample carbon in three radiochemical steps: 1) under dynamic vacuum sample carbon was first combusted to carbon dioxide 2) it was reacted with lithium metal to get acetylene 3) finally benzene was catalytically synthesized from acetylene. Residual radiocarbon activity of the sample benzene was measured by liquid scintillation counter (LKB-QUANTULUS). All the estimated ages reported here was calibrated using online version (http:// www.calib.qub.ac.uk) of the programme Calib 6.1 (STUIVER

Tab. 1: Lava flows in the Terna River basin (Modified after GSDA, 1973-74).

\begin{tabular}{|c|c|c|c|}
\hline Sr. No. & Flow No. & Lithology of the flow & Altitude range $[\mathbf{m}]$ \\
\hline 1 & $\mathrm{IX}$ & $\begin{array}{l}\text { Highly jointed compact basalt flow [fine grained massive and moderately } \\
\text { weathered] }\end{array}$ & 746.00 to 722.00 \\
\hline 2 & VIII & $\begin{array}{l}\text { Jointed compact basalt flow [fine grained massive and moderately } \\
\text { weathered] }\end{array}$ & 722.00 to 685.00 \\
\hline 3 & VII & Highly weathered vesicular amygdaloidal basalt flow & 685.00 to 675.00 \\
\hline 4 & $\mathrm{VI}$ & $\begin{array}{l}\text { Jointed compact basalt flow [fine grained massive, grey to dark grey } \\
\text { coloured and poorly weathered] }\end{array}$ & 675.00 to 643.00 \\
\hline 5 & -- & Red bole bed & 643.00 to 642.00 \\
\hline 6 & $\mathrm{~V}$ & Compact basalt flow [fine grained massive and moderately weathered] & 642.00 to 634.00 \\
\hline 7 & -- & Red bole bed & 634.00 to 633.00 \\
\hline 8 & IV & Highly weathered vesicular amygdaloidal basalt flow & 633.00 to 621.00 \\
\hline 9 & III & $\begin{array}{l}\text { Jointed compact basalt flow [fine grained massive, dark grey coloured } \\
\text { and highly to moderately weathered] }\end{array}$ & 621.00 to 580.00 \\
\hline 10 & II & Poorly weathered vesicular amygdaloidal basalt flow & 580.00 to 569.00 \\
\hline 11 & I & $\begin{array}{l}\text { Jointed compact basalt flow [fine grained massive, dark brownish } \\
\text { coloured and poorly weathered] }\end{array}$ & 569.00 to 551.00 \\
\hline
\end{tabular}




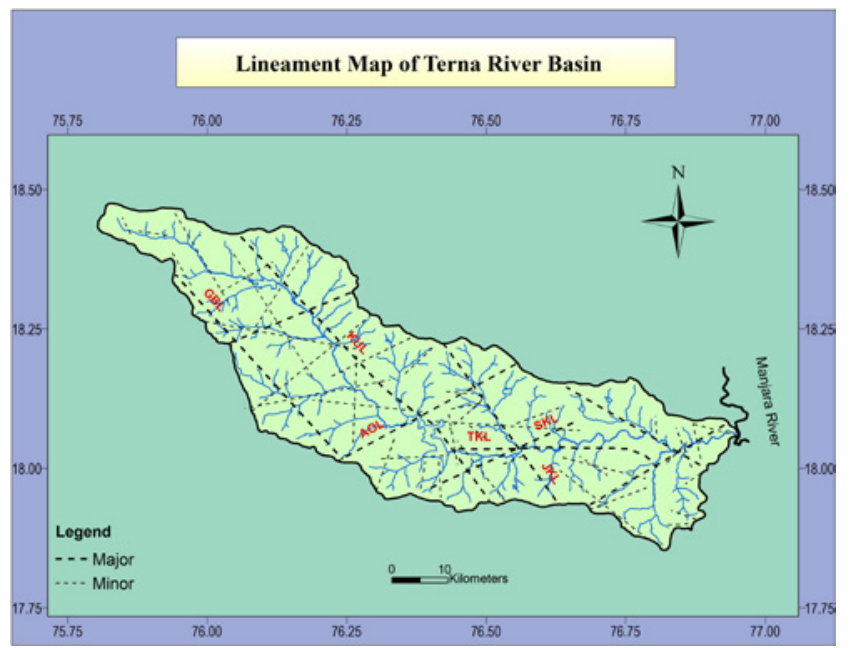

Fig. 3: Lineament map of the study area showing lineaments occurring along NE-SW, NW-SE, E-W and WNW-ESE directions (Modified after ARYA et al. 1995 and SRIVASTAVA et al 1997). TKL - Terna-Killari Lineament, SKL - Sastur-Killari Lineament, AOL - Ausa-Osmanabad Lineament, fKL - Jawalganala-Killari Lineament, KUL - Kallam-Umarga Lineament, GBL - Ghod-Bhima Lineament.

\& REIMER 1993). In most of the cases estimated radiocarbon ages when calibrated results into several age ranges with varying relative area (or probability). For simplifying the discussion, here we consider only those ranges which have high corresponding relative area ( $>0.89$, given in column 5 , Tab. 4). For further details on the procedure refer the STUIVER ひ REIMER (1993).

\section{Results}

\subsection{Quaternary Sediments}

In the Deccan Peninsular India Quaternary deposits are primarily fluvial. They are confined to very narrow belts along rivers with not much recognizable landscape features, except for the sediments recognized along Tapi and Purna rivers (GHATAK \& GHATAK 2008; TIWARI et al. 1996; TiWARI \& BHAI 1997b; TIWARI \& BHAI 1998; TIWARI 1999; TIWARI 2001; TIWARI et al. 2010). These deposits are often discontinuous, generally unfossiliferous and lack suitable material for radiometric dating, further more; the deposits lack proper preservation of pollen and proper sedimentological record.

The lithology of the Terna valley of older alluvium consists of dark grey sand and silts with grey brown clay and at some places development of calcretes suggests that the Older Quaternary Alluvial deposits are of Upper Pleistocene age. Lithostratigraphically the Quaternary deposits of the Terna River basin have been divided into three informal formations including (i) dark grey silt formation - Late Holocene, (ii) Light grey silt formations - Early Holocene, (iii) Dark grayish brown silt formation - Late Pleistocene. There are two formations of Holocene age including early and late Holocene, which are equivalent of the Ramnagar and Bauras formations of Narmada alluvium (TIWARI \& BHAI 1997). The Quaternary sediments observed in the area are present floodplain (To), older floodplain (T1) and pediplain (T2). The fine clay and silt formations in the lower reaches reflect that the streams are of low gradient and more sinuosity. In this area monsoon is the most dominating parameter controlling

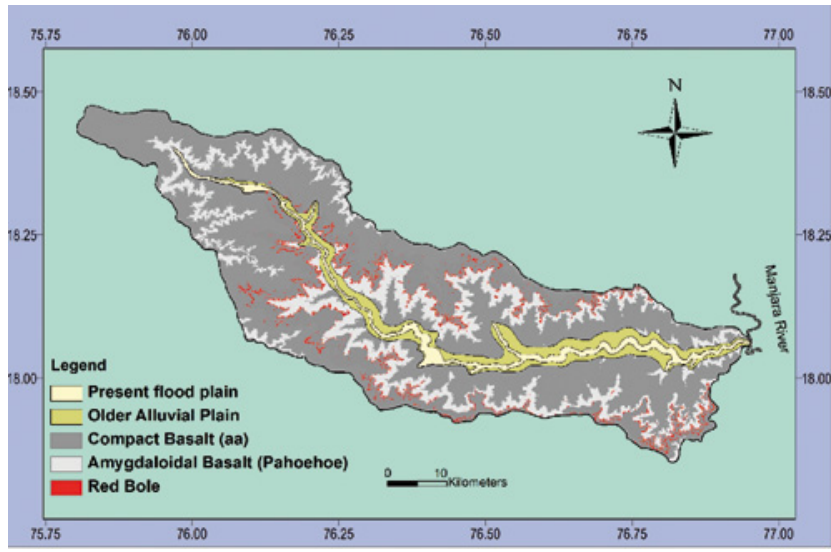

Fig. 4: Geological Map of the Terna River Basin.

the behavior of the river. The highly seasonal rainfall results in the highly seasonal discharge in the river. Most of the geomorphic work is done during the flood events that occurred during individual storm at the end of monsoon. A large part of the alluvial record is therefore produced during flood and this is well illustrated by the fineness in the sediments (BULL 1991; Nanson \& Toотн 1999; Schumm 1978; Mishra et al. 2003).

\subsection{Morphostratigraphy of Terna River Sediments}

Alluvial plain of the Terna River shows 3 terraces namely, T0, T1, T2 in increasing order of elevations (Tab. 2). These terraces were described as suggested by TIwARI \& BHAI (1997b) and BABAR et al. 2010 with reference to the soil types and soil characteristics.

The lithostratigraphic formations have been identified on the basis of nature of sediments, sedimentary structures and pedogenic characters. Thus we have four lithostratigraphic formations.

The dark grey sand and silt with grew brown clay formation is correlated with upper Hirdepur formation of late (upper) Pleistocene age (13 ka to $25 \mathrm{ka}$ ). The Gray Sand and Silt formation and dark grey silt formation is correlated with the Ramnagar formation of late Holocene age (2 ka to $5 \mathrm{ka}$ ) (TIWARI 1999).

\subsection{Lithologs of sediments exposed along Terna River}

The lithologs of the Quaternary sediments are studied from the source area of the Terna River at Terkheda to the confluence with Manjra river at Aurad Shahjani. The important localities of the litholog studied are Yermala, Rui, Ter, Borgaon, Ujni, Makhni, Duta, Sastur, Sawari, Gunjarga, Aurad Shahjani and Wanjarkheda (Fig. 5).

At Yermala highly jointed compact basalt (aa type) lava flow is exposed on the right bank, while on left bank there is exposure of $6 \mathrm{~m}$ thick sediment consisting of the grey clayey soil followed by pebbly gravel, sandy silt and sandy gravel (Fig. 5 a). The litholog (Fig. 5 b) at Rui is $5.7 \mathrm{~m}$ thick and consist of grey clayey soil followed by sandy silt, clay, sandy silt and pebbly gravel along with compact basalt at bottom. The surprising element in the Terna River basin is the thickness of about $15 \mathrm{~m}$ of Quaternary sediment at Ter. The river bluff 


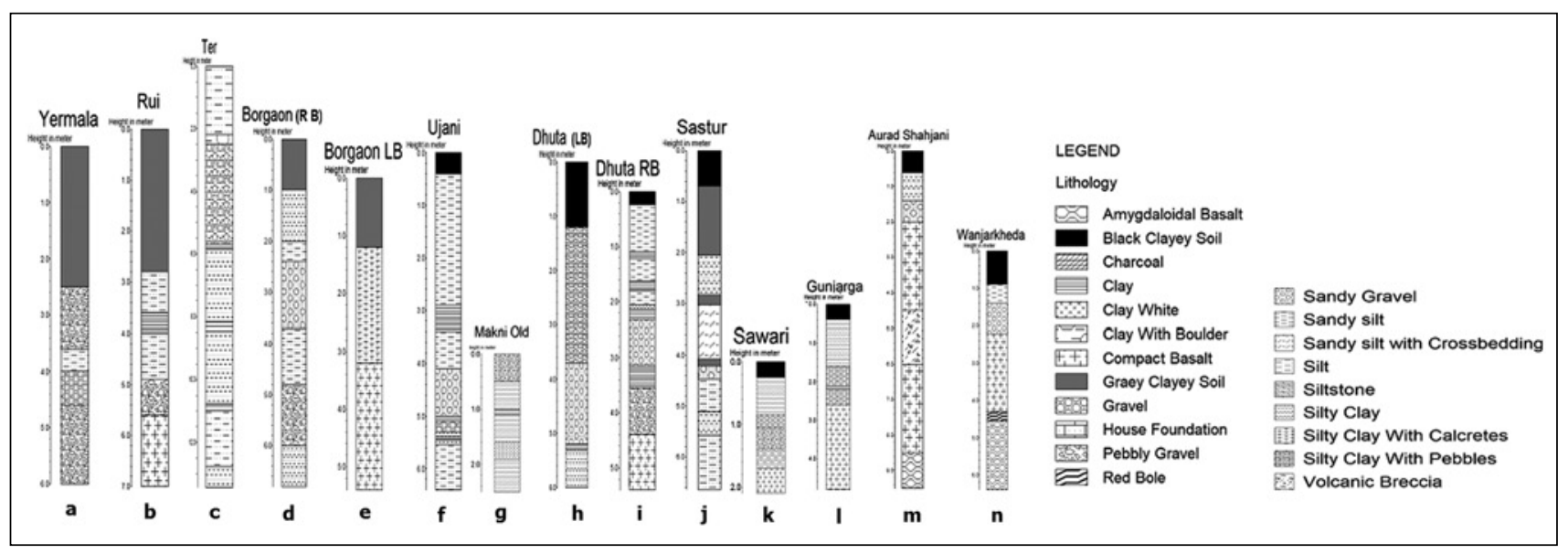

Fig. 5: Lithologs of the sediments observed along the Terna Valley. a to $n$ indicates the exposed lithologs at different localities.

at Ter village (Fig. 5 c) in Latur District is occurring on the western bank of the Terna River.

The Quaternary sediments section occurring along the right bank of Terna valley at Borgaon (Fig. $5 \mathrm{~d}$ ) is $6.8 \mathrm{~m}$ thick. The section shows the silty clay at the base resting over the present level of the floodplain followed by grayish black pebbly gravel, light grey sandy silt, dark grey sandy gravel followed by grey sandy silt and grey silty clay intercalated with thin clay layers and grey clayey soil at the top (Fig. $5 \mathrm{~d}$ ). There is less thickness of sediment on the left bank of the Terna River i.e. $3.2 \mathrm{~m}$ consisting of top most grey clayey soil followed by grey silty clay with calcretes and jointed compact basalt at the base (Fig. 5 e).

The Quaternary sediment found along the Terna valley at Ujni (Fig. $5 \mathrm{f}$ ) is $6.4 \mathrm{~m}$ thick. The section shows sandy silt at the base followed by alternate layers of silt and clay, pebbly gravel layer, grey black clay, sandy gravel, sandy silt, clay and major sandy silt layers in upward succession. The topmost layer is the black clayey soil. The major sequence of this section is the thick massive grey sandy silt.

The litho-section along left bank of the Terna River is occurring at Makni village (Fig. $5 \mathrm{~g}$ ) and having total thickness of $2.4 \mathrm{~m}$. The section consists of silty clay at the base, which is followed by the dark sandy layer, silty clay, grey brown clayey soil, light grey silty clay in upward succession with top most grey black silty clay with pebbles.

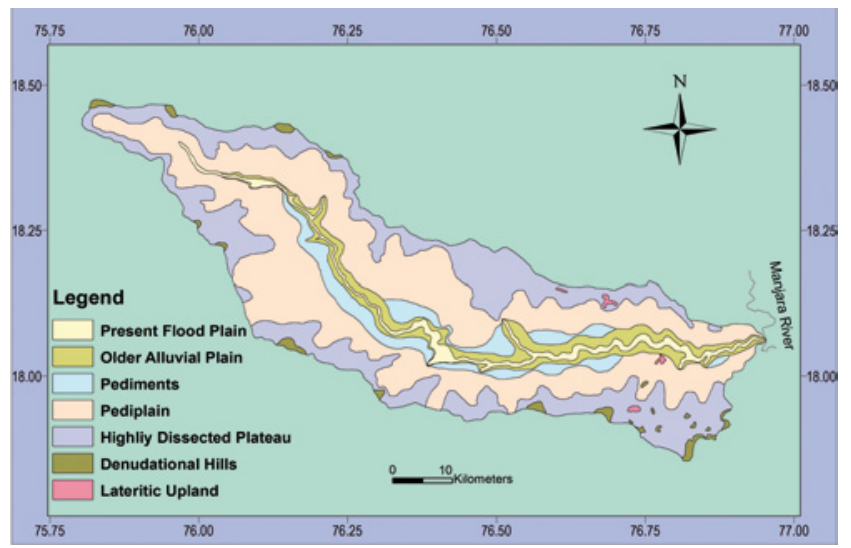

Fig. 6: Geomorphic surfaces of Terna River Basin.
The two exposures of Litho-section at Dhuta are found at left bank (Fig. 5 h) and right bank (Fig. 5 i). The left bank section $(6 \mathrm{~m}$ thick, Fig. $5 \mathrm{~h})$ shows sandy silt $(0.60 \mathrm{~m})$ at the base followed by alternate layers of clay $(0.20 \mathrm{~m})$, sandy gravel layer $(1.50 \mathrm{~m})$, and silty clay with pebble $(2.50 \mathrm{~m})$ as a major layer in upward succession. The topmost layer is the black clayey soil $(1.20 \mathrm{~m})$. The sedimentary section observed along the right bank of Terna valley at Dhuta village (Fig. 5 i) is 6.8 $\mathrm{m}$ thick. This section is developed as the compact basalt at the base followed by pebbly gravel $(0.85 \mathrm{~m})$ grayish brown clay (0.40), sandy gravel $(0.82 \mathrm{~m})$, alternating layers of silty clay and light grey clay and black clayey soil $(0.24 \mathrm{~m})$ at the top.

The Quaternary sediments along Terna valley at Sastur (old) village (Fig. $5 \mathrm{j}$ ) is $6.8 \mathrm{~m}$ thick. This section is developed as the grey brown sandy silt at the base followed by grayish brown clay bed, grey brown sandy silt layer, sandy gravel, which is overlain by Grey clayey soil. Above clayey soil bed there is a layer of Sandy silt showing cross bedding structure followed by light grey clayey, silt, light grey clayey and black clayey soil.

The litho-section along left bank of the Terna River is occurring at Sawari village (Fig. $5 \mathrm{k}$ ) and having total thickness of $2.0 \mathrm{~m}$ with $0.4 \mathrm{~m}$ jointed compact basalt exposed at the base. The Quaternary sediment (1.6 m thick) exposed consists of gravel at the base, which is followed by the silty clay with gravel, sandy gravel, silty clay and black clayey soil at the top. The similar section is also visible at Gunjarga (Fig. 5 l) with jointed compact basalt at the base and Quaternary sediments of $2.5 \mathrm{~m}$ thickness.

The sedimentary sections at Aurad Shahjani (2 m thick, Fig. $5 \mathrm{~m}$ ) and Wanjarkheda (2.2 m thick, Fig. $5 \mathrm{n}$ ) near confluence of Terna River with the Manjra river, show the similarity in the Quaternary sediment such as the black clayey soil at the top followed by silt and then sandy gravel with jointed compact basalt at the base. The exposure of basalt flows show differences in these two areas. At Aurad Shahjani there is exposure of Amygdaloidal basalt at the base followed by jointed compact basalt flow, volcanic breccia and jointed compact basalt, whereas at Wanjarkheda there are two lava flows including Amygdaloidal basalt flow at the base followed by jointed compact basalt flow and both are separated by red bole bed. 


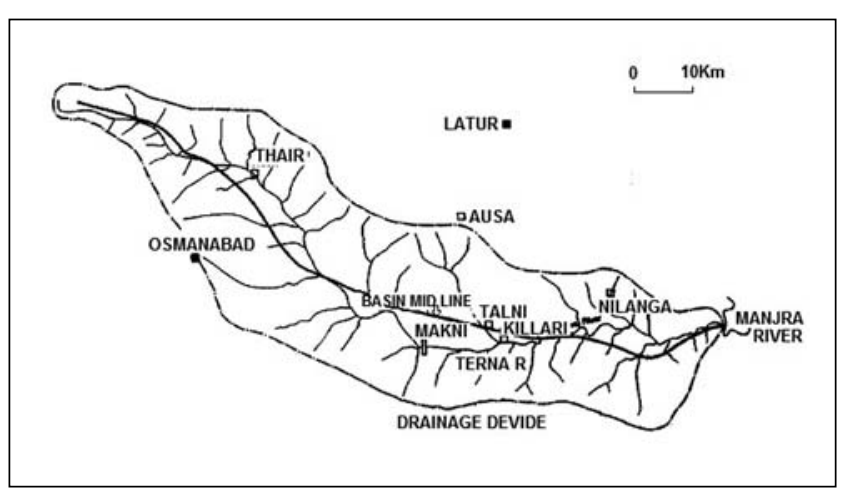

Fig. 7: Drainage morphology of Terna River basin showing the migration of river course (after CHETTY 2006).

\section{Geomorphic Characteristics}

The Terna River basin has been divided in to six geomorphic surfaces: present floodplain, older alluvial plain, pediplains, highly dissected plateau, denudational hills and lateritic upland (Fig. 6) based on the topographic features, morphological characteristics and IRS P6 LISS-III satellite imagery. Towards the source of the basin, i.e. in western and northwestern part, the area is characterised by the moderately steep gradient, rocky upland with deep and narrow valleys and moderately steep longitudinal profile. Such features are due to Quaternary tectonic uplift as found in upland Maharashtra (PowAR 1993; RADHAKRISHNA 1993; RAJAGURU et al. 1993). The uplifted terrace, escarpment, deep grooves, dissected colluvium and a general youthful topography are believed to be indicative of tectonic uplift during the Quaternary.

The middle zone of the basin corresponds to shallow and gently sloping pediplain. The Quaternary sediments directly overlie Deccan Basalt in the pediplain zone. The third zone towards the confluence with Manjra River includes the area of Pleistocene-Holocene alluvial deposits. The development of gullies and badlands in this zone suggests active denudation processes, which may be attributed to the Quaternary tectonic uplift.

Based on geomorphic characteristics of Terna River and locations of archaeological sites, complex surface deformational features and the shallow focal depth consideration, it is suggested that block rotation tectonics about the vertical axis seems to have played a crucial role in causing such a deadly earthquake of magnitude 6.3 (CHetry 2006). The block structure of the basalts also shows considerable influence on the behaviour of seismic waves across the block boundaries. The seismic energy might have been channelled along the boundaries and interfaces amongst different compositional flows. It is inferred that the block rotation model for the basement tectonics could be responsible for the continued tectonic activity in Eastern Dharwar Craton (EDC) and in turn the inherited structural fabric and reactivation tectonics in the overlying Deccan traps.

Two major sets of lineaments trending NW-SE and ENEWSW are inferred from satellite data (CHETTY \& RAO 1994) revealing a well-developed mosaic of block structure (Fig. 3), similar to that described in the EDC. Orientation of structural and lineament fabrics in the Latur region mimics those of the adjacent pre-Deccan basement regions. It is most probably the reflection of structural inheritance of the basement. The mechanism for this transmission is probably related to movements along the reactivated ancient structures in the basement exerting profound control in generating fractures and small-scale displacements in the overlying basalts. While some of the inferred lineaments terminate against the east-flowing Terna River course, sinistral strike-slip displacements could be seen along the ENE-WSW lineaments. Gravity maps (Mishra et al. 1998) exhibit many localized gravity highs and lows of 3-5 mgal coinciding with the major NW-SE striking lineaments in the region. The geomorphic features associated with Terna River (CHETTy \& RAo 1994) indicate that it follows a tectonically active lineament. Further, several archaeological sites along NW-SE trending lineament are also observed along the Terna River. RAJENDRAN \& RAJENDRAN (1998) inferred that one ancient earthquake of $\mathrm{AD} 450$ had occurred around one such archaeological site near Ter.

Examination of the Terna basin and its morphology reveals the shift and migration of the river course in an alternating changing fashion (Fig. 7). Migration of the river course is inferred based on the imaginary midline drawn on the basis of the symmetry of the river basin. In the northwestern part, the river course is east-west, and the migration is towards south. The migration direction changes in accordance with the change in direction of the river course. Further, it is also evident that the lineament fabric pattern influenced the river course (Fig. 3). Interestingly, the location of the archaeological site at Ter, lies at the intersection of two major lineaments. The topographic profile along the Terna River (Fig. 8) shows steep gradient until the river takes an eastward direction, $10 \mathrm{~km}$ west of Killari. The gradient becomes zero near Killari and further east. There is a gradual change not only in the gradient, but also in the regional topography from $\sim 700 \mathrm{~m}$ in the northwest to $560 \mathrm{~m}$ in the east. The main shock and aftershock activities are restricted to the region of lower elevation. Considerable influence of the lineament fabric on the topography, drainage pattern as well as on the river gradient is evident.

Any tectonic deformation that changes the slope of a river valley will result in corresponding changes in sinuosity so as to maintain an equilibrium channel slope (Keller $\mho$ PIN-

Tab. 2: Morphostratigraphy of Terna Alluvium.

\begin{tabular}{|c|l|l|l|c|}
\hline Terrace & Origin & Soil Type & Soil Characteristics & Av. Elevation m amsI \\
\hline TO & Depositional & Entisol [I] & Dark Gray Sand and Silt & 574.0 \\
\hline T1 & Erosional & Inceptisol [II] & Gray Sand and Silt & 582.5 \\
\hline T2 & Depositional & Vertisol [III] & $\begin{array}{l}\text { Dark Gray Sand and Silt with Gray } \\
\text { Brown Clay }\end{array}$ & 591.0 \\
\hline
\end{tabular}




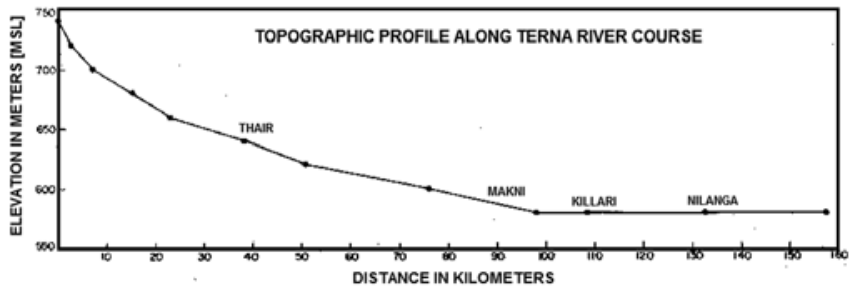

Fig. 8: Topographic profile along Terna River showing steep gradient before becoming flat (after CHETTY 2006).

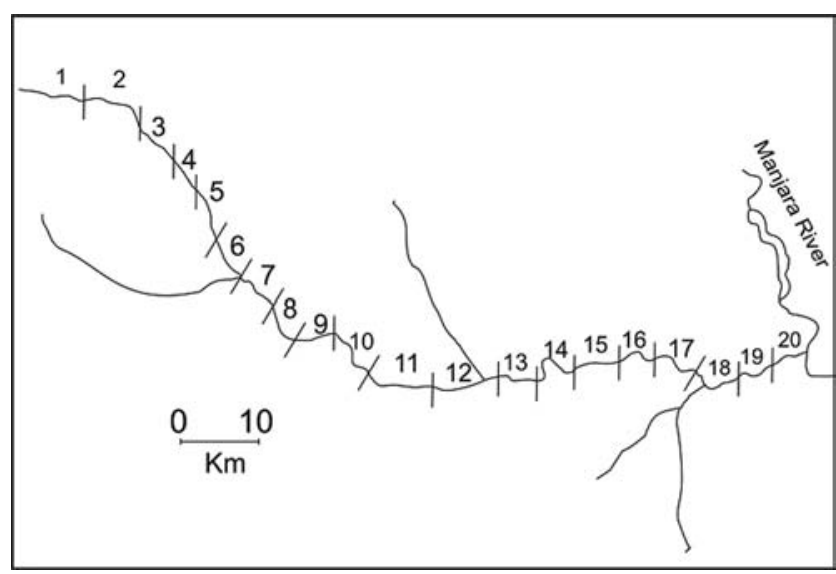

Fig. 9: Map showing segments studied for sinuosity.

TER 1996). Thus sinuosity parameters can be used to deduce the role of tectonism development of channel morphology (eg. Gomez \& Marron 1991; Rhea 1993; Rachna Raj et al. 1999). The sinuosity of a meandering stream is the result of topography and hydraulic factors, which can be expressed by a ratio called the index of sinuosity (Muller 1968). The river channel is divided into number of segments (Fig. 9) as suggested by Muller (1968) and FrIEND \& SinHA (1988) for determination of sinuosity parameter. The measurements of channel length (CL), valley length (VL) and the shortest distance between the source and the mouth of the river (AL), i.e. air lengths are used for calculation of channel index, $\mathrm{CI}=\mathrm{CL} /$ $\mathrm{AL}$ and valley index VI=VL/AL. The standard sinuosity index is calculated using SSI $=\mathrm{CL} / \mathrm{VL}$, hydrological sinuosity index $\mathrm{HIS}=\%$ equivalence of $\mathrm{CI}-\mathrm{VI} / \mathrm{CI}-1$ and topographical sinuosity index TSI $=\%$ equivalent of VI- $1 / \mathrm{CI}-1$. The standard sinuosity index (SSI) for the Terna River channel varies from 1.002 to 1.76 (Tab. 3). The increase in SSI in the lower reaches of the basin is accompanied by lower values of Hydraulic Sinuosity Index (HSI), which suggests that the hydraulic factor is not responsible for increase in SSI in the lower reaches. The values of HSI vary from 2.13 to 85.58 (Tab. 3).

Low values of HSI and correspondingly higher values of Topographic sinuosity index (TSI) in the upland areas and pediment zone suggests that the meandering streams do not belong to the initial denudation cycle (FrIEND \& SINHA 1988), but the present area has been rejuvenated there by indicating the role of tectonism. As the river progresses in the cycle of erosion, the role of hydraulics increases and the role of topography decrease (RACHANA RAJ et al. 1999). This is observed in the lower reaches of the area; where there is a relative increase occurs in HSI though it remains substantially lower than TSI (Tab. 3).

\section{Discussion}

The Peninsular Shield of India was supposed to be seismically stable, but the 1993 Latur earthquake indicated the seismic vulnerability of the area. The deep drilling in the Deccan Volcanic Province in basalt flows, on both side of 1993 rupture zone provided the evidence of a fault and displacement of about $6 \mathrm{~m}$, at a depth of $220 \mathrm{~m}$ (GuptA et al. 1998). Down dip slickenlines on the steep dipping slickenside surface in the drill cores confirm dip slip nature of the fault. However the observed displacement is too much to account for a single earthquake of Mw 6.1, hence they suggested repeated seismicity in the area. RAJENDRAN \& RAJENDRAN (1999) suggested the reactivation of the pre-existing fault and evidence of earlier seismicity in the area by trenching in the rupture zone of 1993 earthquake near Killari. While SukHiJA et al. (2006) find the wide spread geological evidence of a large paleoseismic event near the Meizoseismal area of the 1993 Latur earthquake at Ter on Terna River and Halki and Shivoor on Manjra river.

The deformational structures in the sediments observed are flexures, warps, buckle folds and vertical offset in the sediments (Fig. 10). These structures are earlier studied by RAJENDRAN (1997), RAJENDRAN \& RAJENDRAN (1999) and SukHiJA et al. (2006). The variation in the individual layers that belong to the same deforming mass can be explained by strain partitioning, which depends on the bulk properties of the rock (HATCHER 1995). Because of partitioning of mechanical behaviour, the stiffer and more competent rocks are expected to show variation is shapes and wavelength of folds. From the style of deposition it is clear that buckling of the sediment strata has formed the structures in section at Ter. Here the buckling must have been accompanied by flexural slip between the layers (Fig. 11).

The vertical offset of marker horizons at the northern part of the section (Fig. 12) indicates a displacement of 10-15 cm. The up thrown block is on the southern side of the offset plane. These features are observed in the $15-20 \mathrm{~cm}$ thick inter layers of whitish clay in blackish clay.

Detailed assessment of morphological and morphometric characteristics have confirmed the role of neotectonism in the evolution of Terna River basin. The relative degree of tectonic activity is also manifested by the anomalous behaviour of the streams such as right angled turn of the streams, convergence and divergence of stream, streams flowing parallel to main river for a considerable distance and offset drainage (BABAR et al. 2000). All the parameters in general, suggest an increasing degree of tectonic activity from lower reaches towards the upland source region. The alignments of the significant morphological features and stream orientations have provided information about the linear tectonic elements. The anomalous behaviour of streams indicates that subsurface faulting may be controlling the drainage patterns of the basin (KAPLAY et al. 2004).

The orientations of the stream channels in the upland zone and in the middle reaches of the Terna River basin have been guided by lineaments, which are the indicators of recent tectonic activity. Higher order stream channels reflect the general NW-SE and E-W trend. These trends have been reactivated in recent times as shown by displaced Quaternary deposits (RAJENDRAN \& RAJENDRAN 1999). The offset 
in the sedimentary section at Ter (Fig. 10, 11 and 12) reflects only a fraction of movement in the basement fault below the basalt flows. On the basis of seismogenic features exposed in the sedimentary sections including flexures, warps, buckle fold and vertical offsets. RAJENDRAN (1997) marked the signatures of pre-existing earthquake ( 1500 year ago). These deformational features may be the result of reactivation of NW-SE trending fault. These older tectonic directions, although active until very recent times, had conditioned the drainage network in an earlier period. The TSI values indicate rejuvenation of the area leading to the dominating effect of topography on the sinuosity of the river channels. The break in slope in the long profile is also indication of the Quaternary tectonic uplift of the area. Additional support for the neotectonic activity in the upland zone and middle zone of the Terna River basin is provided by valley floor ratios and longitudinal profile. Morphometric analysis has thus been useful in delineating areas with differing levels of tectonic activity in the basin (BABAR et al. 2009).

The reactivation of pre-existing basement structures was proposed by CHETTY \& RAO (1994), while KAYAL (2000) opined that the Latur earthquake could be due to interac-

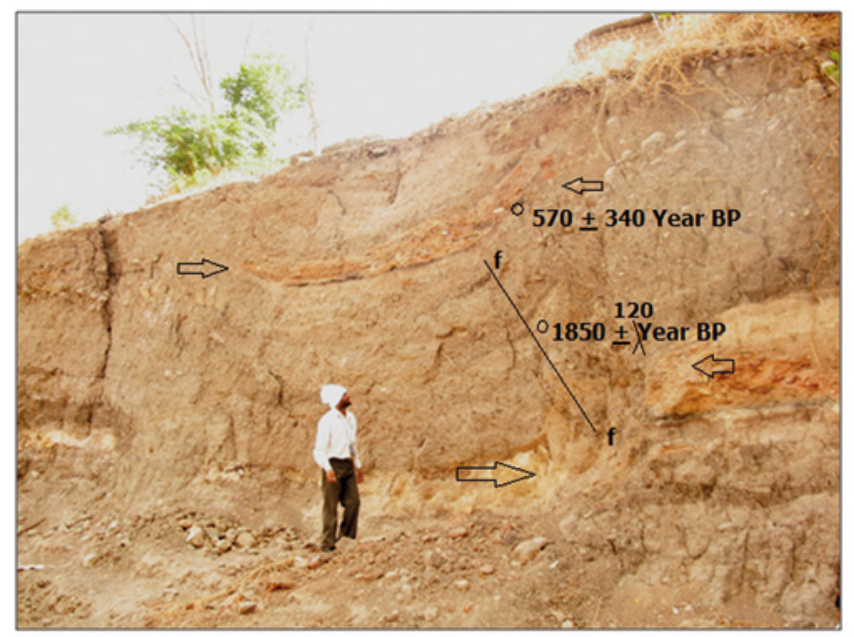

Fig. 10: Quaternary Sediments at Ter showing folding in upward section and faulting $(f-f)$ in the middle part. The upper layer is marked with the pottery layer showing the warping (Location is given in Fig. 2). Arrows indicate the direction of compression for folding and horizontal shortening.

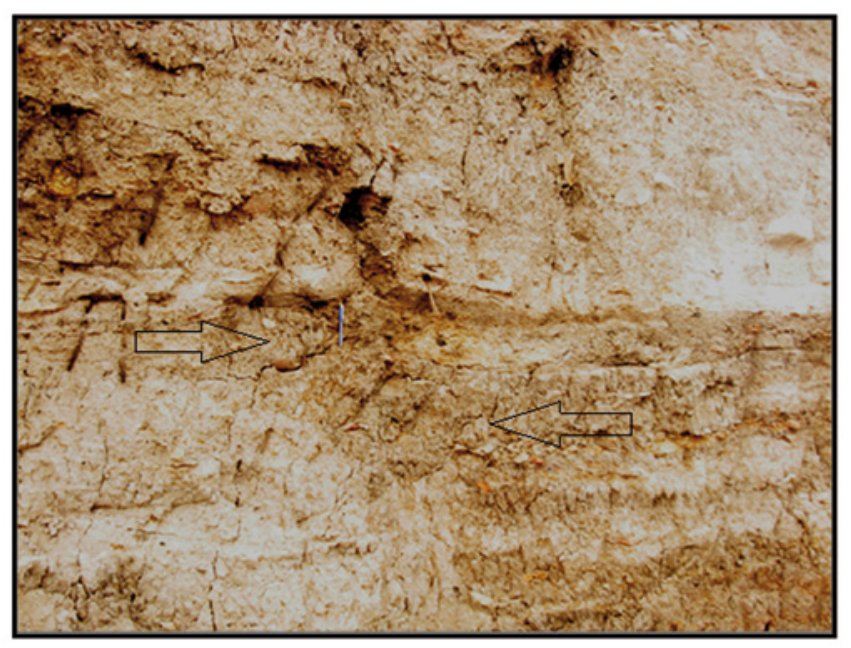

Fig. 11: Photograph showing the flexure and horizontal shortening in the sediment at Ter village.

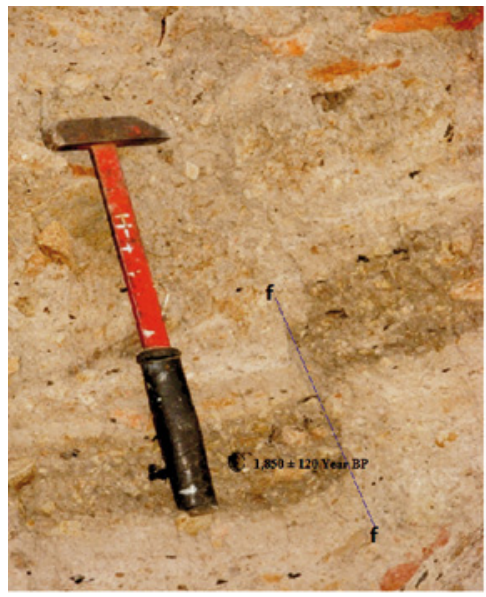

Fig. 12: Close-view of offset in middle of the section at Ter shown in Fig. 10.

tions of two shallow crustal faults. However, CHETTy (2006), proposed an alternative explanation in terms of block rotation tectonics as a plausible mechanism for the Latur earthquake. According to him based on the structural fabric in the EDC, as derived from satellite data as well as aerial photos, and the unusual shapes, sizes and geometry of mafic dykes and distinct fault systems, block rotation tectonics with clockwise rotations were inferred from the deformational system of the EDC. Block rotation is a significant mode of deformation in the earth's crust (FreUnd 1970; KISSEL \& LAJ 1989; McKenzIE \& JACKSON 1986). The Latur region lies in the proximity of the Kurudwadi lineament, earlier described by Brahmam \& Negi (1973) as a subtrappean rift on the basis of gravity anomalies. Based on geomorphic studies using satellite data and aerial photos, PeshwA \& KALE (1997) concluded that this is a Precambrian deep crustal-scale shear zone comprising an array of NW-SW trending faults along which dextral sense of movements have taken place, even during the Quaternary period. This is evident from the parallelism of the drainage network with the Kurudwadi lineament, suggesting the control of basement structures in their development. These movements based on the presence of sheared segments of the Archean gneisses were also responsible for the secondary development of east-west trending faults identified by gravity studies. Structural architecture of the Latur earthquake region presented in this study favours the block rotation model, which could be a part of dextral sense of shear along the NW-SE trending lineaments (CHETTY 2006).

The seismicity associated with the Killari source is comparable to those in other cratons, such as Australia. Interestingly, location of historic earthquakes during AD 12011960 (Geological Survey of India) appears to be mostly confined to a 400-km-long NW corridor passing through Killari (Fig. 1). Spatial correlation of this corridor of activity with a structure inferred from a variety of data as well as the fault plane solution of the main event suggested reactivation of a NW-oriented fault (RAJENDRAN \& RAJENDRAN 1999). Search for palaeoearthquakes in the vicinity of Killari led to the identification a deformation event dating to $\mathrm{AD} 350-450$, at a location known as Ter, about $40 \mathrm{~km}$ northwest of Killari (RAJENDRAN 1999). The data on age dating of the charcoal samples varies from AD 120 to AD 1671 and is given in Table 4. In the present study the calendar ages of the deformed section at Ter is found to be between $\mathrm{AD} 1151$ to $\mathrm{AD}$ 


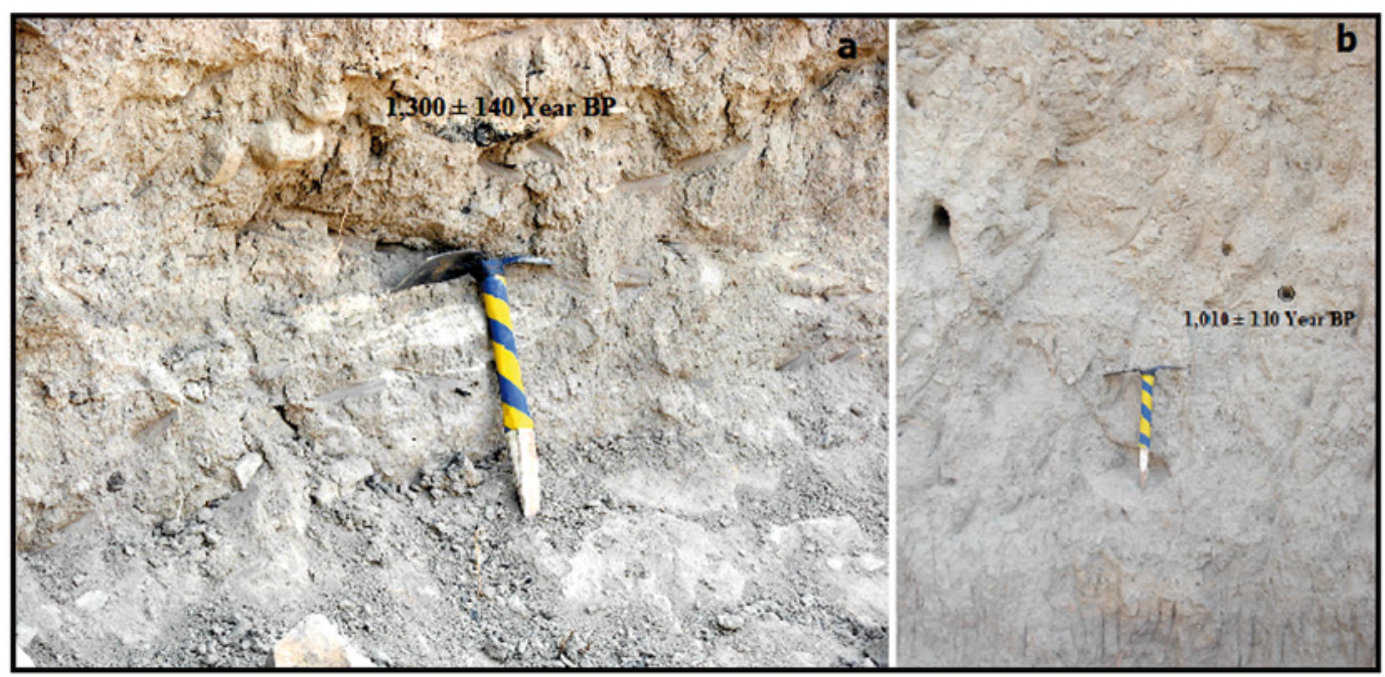

Fig. 13: (a) Sediment section at Makni showing deformation in silty clay formation, (b) Sediment section at Dhuta along the left bank of Terna valley.

353, while for the deformed sections at Dhuta and Makhni the corresponding calendar ages are between $\mathrm{AD} 650$ and AD 1183. Similarly, the deformed structure at Killari (Fig. 14) indicates the dates are between AD 1256 and AD 1454.

The litholog of Quaternary sediments occurring along the left bank of Terna valley at Dhuta (Fig. $5 \mathrm{~h}$ ) is $6.0 \mathrm{~m}$ thick. The section shows the silt at the base resting over the present level of the floodplain followed by grayish black pebbly gravel, light grey sandy silt, dark grey sandy gravel followed by clay, grey sandy gravel and thick grey silty clay with pebble and black clayey soil at the top. The charcoal sample from this sediment (Fig. 13 b) has been dated and found the age of $1010 \pm 110$ year B.P. (Tab. 4). The sedimentary section on the right bank of the Terna River at Dhuta is $4.4 \mathrm{~m}$ thick and quite different than the left bank section. It consists of top most black clayey soil followed by alternate layers of sandy silt and clay, which is succeeded by sandy gravel, clay and pebbly gravel (with subangular pebbles) and jointed compact basalt occurs at the base (Fig. 5 i).

The epicenter of Latur 1993 earthquake old Killari village is located on the left bank of the Terna River and has an approximately $08 \mathrm{~m}$ thick layer of alluvium topped by the anthropogenic dump. The deposit is in the form of a mound

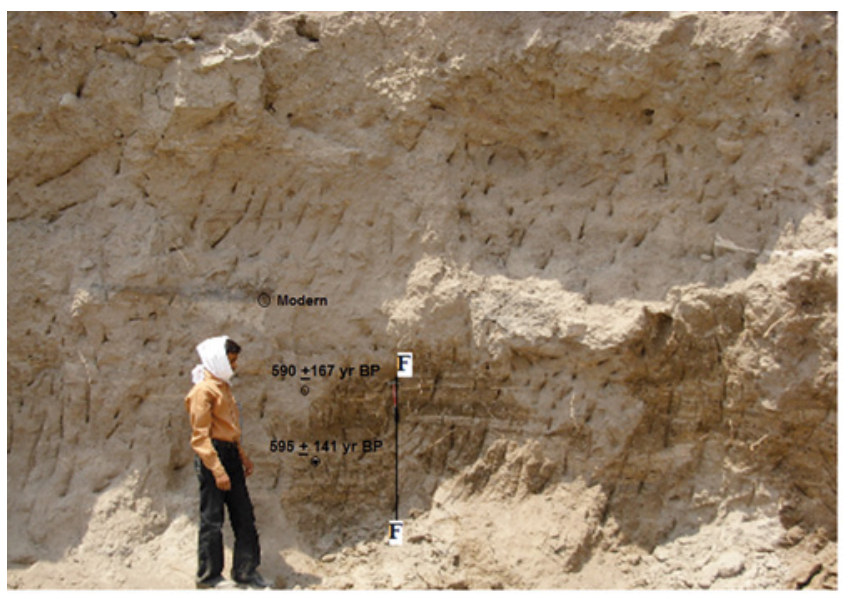

Fig. 14: Sediment section at Killari showing Fault at a depth of $6.20 \mathrm{~m}$. occurring below the ruins of the Killari-Latur earthquake of 1993. The trench is developed in this region because of the fact that the local people are excavating the soil for the purpose to use it as a fertilizer. The alluvium is highly dissected and now represented by irregular excavated mounds. Old Killari village was spread over these mounds, now nothing left except the Nilkantheshwar Temple and remains of earthquake affected dump.

The bluffs in general show evidences of deposition by river surges and are marked by alternating layers of coarse sands with cobbles and silty clay. The courser layers may have been deposited during the floods and fine sediments during the leaner seasons. Texturally the sediments can be classified as clay loam, sandy clay and silty clay loam. These types of sediments have been noted for major rivers in Maharashtra and are categorized as flood loams or diluvium (RAJAGURU \& KALE 1985). These rivers are noted for highly fluctuating discharge and active channel migration (RAJAGURU et al. 1993). In the Ter village section, in a pit at the base of bluff, it is found that the alluvium extends $>2 \mathrm{~m}$ below the present riverbed. This probably suggests that fluvial processes at Ter (RAJENDRAN 1997) must have started much earlier, analogues to other rivers in Maharashtra and the same is the case of the Killari area.

The well-exposed vertical section of the mound along the left (southern) bank of the Terna River, was selected for paleoseismic investigation, this $8 \mathrm{~m}$ thick section (Fig. 10) extends in E-W trending arc measuring about $35 \mathrm{~m}$ long. This section mainly consist of dumped material like broken bricks, pottery, boulders etc for the top $1.5 \mathrm{~m}$, followed by gray clays inter-bedded with varied mixtures of sand, silt and ash in the form of either thin layers or elongated lenses and wedges. The bedding is imperfect and is commonly marked by colour variations in individual layers. The fluvial/ fluvio-lacustrine nature of bottom layers at the depth of 7.5 $m$ is evidenced by the presence of load cast and scour and fill structures deposited in a high-energy environment. Pebble/ stone beddings at that depth.

The site has been modified by human activity and artifacts like pottery, beads, idols, human bones and even large objects like earthen pots and a number of in situ wooden 


\begin{tabular}{|c|c|c|c|c|c|c|c|c|}
\hline Segment No. & $\begin{array}{l}\mathrm{CL} \\
{[\mathrm{Km}]}\end{array}$ & $\begin{array}{l}\mathrm{VL} \\
{[\mathrm{Km}]}\end{array}$ & $\begin{array}{l}\text { AL } \\
{[\mathrm{Km}]}\end{array}$ & CI & VI & SSI & HSI & TSI \\
\hline 1 & 8.60 & 8.52 & 8.36 & 1.033 & 1.020 & 1.014 & 39.39 & 60.61 \\
\hline 2 & 9.72 & 9.70 & 8.52 & 1.141 & 1.138 & 1.002 & 2. 13 & 97.87 \\
\hline 3 & 6.48 & 6.35 & 5.76 & 1.125 & 1.102 & 1.020 & 18.40 & 81.60 \\
\hline 4 & 5.28 & 5.04 & 4.68 & 1.128 & 1.077 & 1.048 & 39.84 & 60.16 \\
\hline 5 & 7.32 & 6.97 & 6.25 & 1.171 & 1.115 & 1.050 & 32.75 & 67.25 \\
\hline 6 & 6.49 & 6.44 & 5.76 & 1.127 & 1.118 & 1.008 & 56.52 & 43.48 \\
\hline 7 & 5.76 & 5.54 & 5.08 & 1.134 & 1.091 & 1.040 & 32.75 & 67.25 \\
\hline 8 & 6.00 & 5.78 & 5.40 & 1.111 & 1.087 & 1.022 & 21.62 & 78.38 \\
\hline 9 & 5.64 & 5.62 & 5.40 & 1.044 & 1.041 & 1.004 & 6.82 & 93.18 \\
\hline 10 & 7.49 & 6.94 & 6.25 & 1.198 & 1.110 & 1.079 & 44.44 & 55.56 \\
\hline 11 & 9.72 & 9.24 & 8.43 & 1.153 & 1.096 & 1.052 & 37.25 & 62.75 \\
\hline 12 & 8.88 & 8.16 & 8.04 & 1.104 & 1.015 & 1.088 & 85.58 & 14.42 \\
\hline 13 & 7.08 & 6.27 & 6.09 & 1.163 & 1.030 & 1.129 & 81.60 & 18.40 \\
\hline 14 & 6.24 & 5.48 & 4.08 & 1.529 & 1.343 & 1.138 & 35.16 & 64.84 \\
\hline 15 & 8.16 & 7.23 & 6.25 & 1.306 & 1.157 & 1.129 & 48.69 & 51.31 \\
\hline 16 & 6.61 & 5.66 & 5.16 & 1.281 & 1.097 & 1.168 & 65.48 & 34.52 \\
\hline 17 & 6.27 & 5.60 & 5.25 & 1.194 & 1.067 & 1.119 & 65.45 & 34.55 \\
\hline 18 & 7.32 & 6.25 & 5.52 & 1.326 & 1.132 & 1.171 & 59.51 & 40.49 \\
\hline 19 & 5.28 & 4.49 & 4.20 & 1.255 & 1.069 & 1.176 & 69.33 & 30.67 \\
\hline 20 & 4.44 & 3.79 & 3.46 & 1.284 & 1.094 & 1.174 & 66.90 & 33. 10 \\
\hline
\end{tabular}

$\mathrm{CL}$ - Channel length, VL - Valley length, AL - Air length, $\mathrm{CI}$ - Channel index, VI - Valley index, SSI - Standard Sinuosity Index, HSI - Hydraulic sinuosity index, TSI - Topographic sinuosity index

posts used for construction of various structures are present in the section. There is a small wedge shaped burnt layer of $10 \mathrm{~cm}$ thickness is found in the section at the depth of $5.7 \mathrm{~m}$ from the ground surface.

The structural feature observed in this section is the northwest dipping normal fault trending N-S (Fig. 14). The observed fault appears to be a secondary manifestation of a deep-seated disturbance in the area. Surface faults are not reported in the region. Ancient faults are likely to be present below the Deccan trap volcanic cover and do not have any direct expression on the surface. Hence, it becomes necessary that geomorphic evidences indicating tectonic activity have to be linked with seismicity via drainage pattern, soft sediment deformation in alluvial and colluvial sediments (CHetty \& RAo 1994). Thus in the absence of surface expression of fault and in view of the presence of several inferred faults in the region, it is thought reasonably to conclude that features observed in this section could the surface manifestation of a deep seated disturbance in the region.

The fault in the section is observed in the variegated clay/ silty clay beds separated by feature less horizon of $3.5 \mathrm{~m}$ thick silty clay. The fault is about $6.2 \mathrm{~m}$ below the ground surface and the observed displacement is about $40-45 \mathrm{~cm}$ of the silty clay bed. The layers above these faulted sediments are undisturbed, while the clay horizon at the lower portion of the fault shows the severity of frictional and compressional forces acting simultaneously on it. It is attributed by the present study that the displacement along the fault and slickensided surfaces of the clay blocks as the surface manifestation of the tectonic disturbance. To assess the possible time of the faulting a number of charcoal samples were col- lected around the fault as well as from the rest of the section.

The well-exposed vertical Section of the mound along the left bank of the Terna River is $3.5 \mathrm{~m}$ thick section (Fig. $15 \mathrm{a}$ ) extends in a NE-SW trending arc measuring about $25 \mathrm{~m}$ long. This section mainly consist of dumped material like broken bricks, pottery, boulders etc for the top $0.35 \mathrm{~m}$, followed by gray clays inter-bedded with varied mixtures of sand, silt and ash in the form of either thin layers or elongated lenses and wedges. The bedding is imperfect and is commonly marked by colour variations in individual layers. The sedimentary unit observed in the section on the whole has been warped at different scales. On a large scale, the entire section appeared to have been folded. Individually, the structures present in the section can be broadly categorized as flexures, warps and buckle fold (Fig. 15 a). The burn layer in the same section shows the folding (Fig. $15 \mathrm{~b}$ ). The structures including warping and low amplitude folding of near surface beds of alternating clay and cohesion less sediment have been reported from the other earthquake prone areas (AUDEMARD $\mho$ DE SANTIS 1991). It was observed that the structures at Killari are better developed on more competent layers such as the layers containing ceramics and pebble foundations made by settlers, although weak traces of folds can be discerned on the argillaceous layers as well, on cluster look. Variation in intensity of deformation observed in individual layers that belong to the same deforming mass can be explained by strain partitioning, which depends on the bulk properties of the rock (HATcher 1995). From the style of the deformation, it is clear that the structure in the section at Killari have been formed by buckling of the sediment strata. 


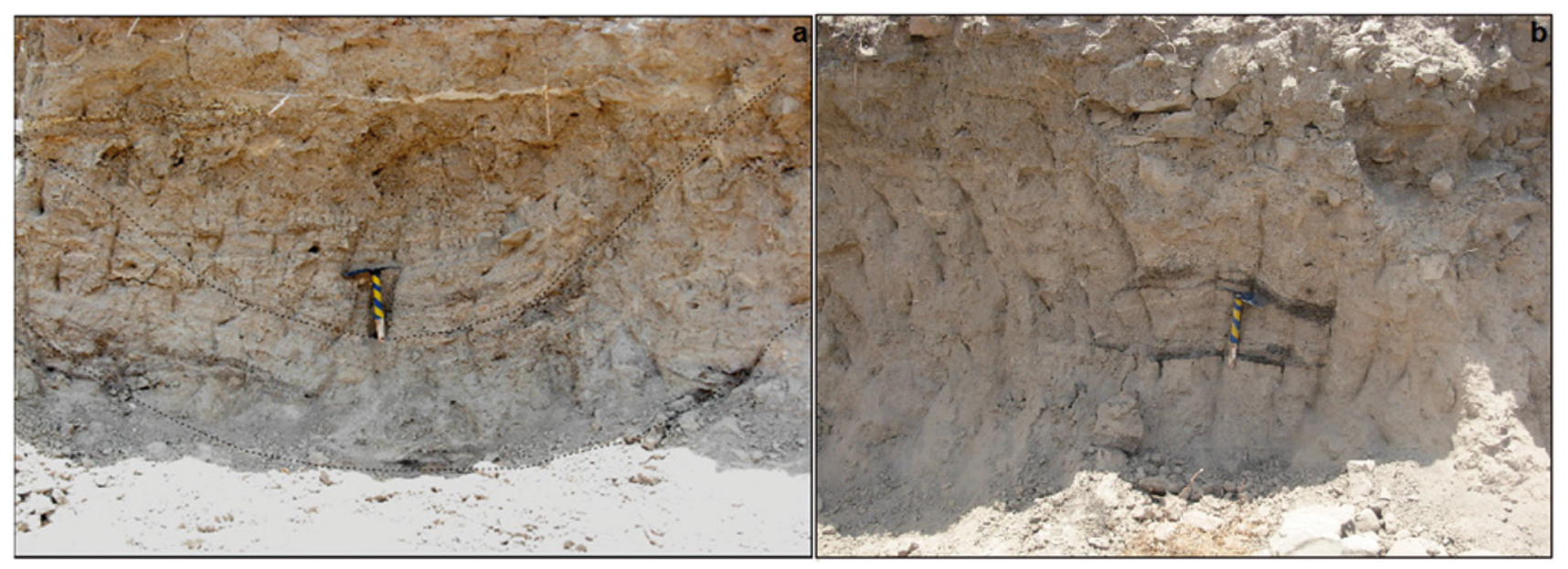

Fig 15: (a) Sediment section at Killari showing Folding in lower part at a depth of $3.87 \mathrm{~m}$, (b) Sediment section at Killari showing Warp at a depth of $2.60 \mathrm{~m}$ in a burn layer.

\section{Conclusion}

The study of lithologs and the description of Quaternary sediments of Terna River basin indicate that there is significant amount of the coarse gravelly deposits along with silty deposits. These deposits are indicator of changes in the hydraulic conditions which are induced by climate or tectonics. The lithology of the Terna valley alluvium suggests that the Older Quaternary Alluvial deposits are of Upper Pleistocene age. Lithostratigraphically the Quaternary deposits of the Terna River basin have been divided into three informal formations including (i) dark grey silt formation - Late Holocene, (ii) Light grey silt formations - Early Holocene, (iii) Dark grayish brown silt formation - Late Pleistocene. The basin area has been divided in to six Quaternary geomorphic units including present floodplain, older alluvial plain, pediplains, highly dissected plateau, denudational hills and lateritic upland. The lineaments occur along NE-SW, NW-SE, E-W and WNW-ESE directions, which control the basement structure in the study area. The TSI values indicate rejuvenation of the area leading to the dominating effect of topography on the sinuosity of the river channels. The break in slope in the long profile is also indication of the Quaternary tectonic uplift of the area. The radiocarbon dating of charcoal samples indicate that the event of palaeoseismic activity might had taken place along the Terna valley from $\mathrm{AD} 971$ to $\mathrm{AD} 1183$ and at Ter it may be AD 1151 to AD 353.

\section{Acknowledgement}

The authors gratefully acknowledge the financial support by DST, New Delhi, under the project F. No. SR/S4/ES-198/2006, dated 05.06.2007. We are also indebted to our College Principal, Dr. P.L. More, for encouragement and constant support for research. We are also very much grateful to Dr. D.V. Reddy for the Radio Carbon dating of Charcoal samples from Killari area KL1 and KL2.

\section{References}

Arya, A.S., Murthy, T.V.R., Garg, J.K., Narain, A \& Baldev S. (1995): Lineament pattern and its possible relationship with Killari earthquake: A case using IRS data. - Geological Survey of India special Publication, 27: 211-214.

Audemard, A. \& DE SAnTis, F. (1991): Survey of Liquefaction structure induced by recent moderate earthquakes. - Bulletin International Association Engineering Geology, 44: 5-16.

Babar, Md., Chunchekar, R.V., Ghute, B.B. ¿ Kaplay, R.D. (2009): Tectonic Geomorphology of Terna-Manjra River Basin, West Central India. - Journal Indian Geological Congress, 1(2): 69-78.

Babar, Md., Ghute, B.B. \& Chunchekar, R.V. (2010): Quaternary Morphostratigraphy and Litostratigraphy of Godavari River sediments in Parbhani District Maharashtra. - Gondwana Geological Magazine, 12: 271-274.

BABAR, MD., KAPLAY, R.D. \& PANASKAR, D.B. (2000): Structural control on drainage pattern in the Terna River Catchment, Central west India. Indian Journal of Geomorphology, 5: 126-133.

Bilgrami, S.Z. (1999): A geological map of the eastern part of the Deccan traps (Bidar-Nagpur). - Memoir Geological Survey of India, 43: 219232 .

Tab. 4: Data on age dating of Quaternary Sediments.

\begin{tabular}{|l|l|l|l|l|l|}
\hline Lab No. & Sample ID & Location & Depth cm & uncal ${ }^{\mathbf{1} C}$ Date year BP & Ref. Fig. \\
\hline PRL-3154 & TTE-1 & Ter & 284 & $570+/-340$ & Fig.10 \\
\hline PRL-3155 & TTE-2 & Ter & 565 & $1,850+/-120$ & Fig.10, 12 \\
\hline PRL-3153 & TMK-2 & Makni & 255 & $1,300+/-140$ & Fig. 13 [a] \\
\hline PRL-3157 & TDU-1 & Dhuta & 211 & $1,010+/-110$ & Fig. 13 [b] \\
\hline PRL-3150 & TKL-2 & Killari & 590 & Modern & Fig. 14 \\
\hline KL-1 & KL-1 & Killari & 610 & $590+/-167$ & Fig. 14 \\
\hline KL-2 & KL-2 & Killari & 622 & $595+/-141$ & Fig. 14 \\
\hline
\end{tabular}

* based ${ }^{14} \mathrm{C}$ half-life $=5730 \mathrm{yr}$ 
Bilham, R. (2004): Earthquakes in India and the Himalaya: tectonics, geodesy and history. - Annals of Geophysics, 47(2): 839-858.

Bose, M.K. (1996): Deccan Basalt, Mantle activity and Extensional Tectonics. - Gondwana Geological Magazine, 2: 267-281.

Brahmam, N.K. \& Negi, J.G. (1973): Rift valleys beneath Deccan Traps (India). - Geophysics Research Bulletin, 11: 207.

BuLL, W.B. (1991): Geomorphic response to Climatic Change. - Oxford (Oxford University press).

ChandRasekHaram, D. (1985): Structure and evolution of the Western continental margin of India deduced from gravity, seismic, geomagnetic and geochronological studies. - Physics of Earth and Planetary Letters, 41: $186-198$.

ChetTy, T.R.K. (2006): Contrasting deformational systems and associated seismic patterns in Precambrian peninsular India. Current Science, 90(7): 942-951.

Chetty, T.R.K. ¿ RaO, M.N. (1994): Latur earthquake of September 30, 1993: Surface deformation and lineament pattern. Memoir Geological Survey of India, 35: 65-73.

Cox, K.G. (1989): The role of mantle plumes in the development of continental drainage patterns. - Nature, 324: 873-876.

Cox, K.G. (1991): A super plume in the mantle. - Nature, 352: 564-565.

FREUND, R. (1970): Kinematics of transform and transcurrent faults. - Tectonophysics, 21: 93-134.

FRIEND, P.F. \& SINHA, R. (1988): Braiding and meandering parameters. - In: Best, J.L. \& Bristow, C.S. (eds.): Braided rivers. - Geological Society of London, 75: 105-111.

GHatak S. \& GHatak M. (2008): Active faulting and its behaviour on the geology, drainage and landscape in Tapi fault. - Gondwana Geological Magazine, 23(1): 31-37.

GOMEZ, B., \& MARRON, D.C. (1991): Neotectonic effects on sinuosity and channel migration, BelleFourche River,Western South Dakota. - Earth Surface Processes and Landforms, 16: 227-235.

GSDA (1973-74): District Appraisal Report. - Groundwater Survey Development Agency (GSDA).

GuPTA, H.K. ひ DwivedY, K.K. (1996): Drilling at Latur earthquake region exposes a peninsular gneiss basement. - Journal of Geological Society of India, 47: 129-131.

Gupta, H.K., Dwivedy, K.K., Banerjee, C.D., Rao, R.U.M., Rao, G.V. \& SHRINIVASAN, R. (1998): Latur earthquake, Maharashtra, India: A case study of a borehole investigation at SCR earthquake site. - Abstract volume Stable Continental Region (SCR) Earthquakes. National Geophysical Research Institute, Hyderabad, India, 39-40.

HATcheR, R.D. (1995): Structural Geology. - Prentice Hall, New Jersey: $525 \mathrm{pp}$.

KAILASAM, L.M. (1993): Geophysical and Geodynamical aspects of the Maharashtra earthquake of September, 1993. - Current Science, 65: 736739 .

Kapley, R.D., Md. Babar, Panaskar D.B. \& Rakhe A.M. (2004): Geomorphometric characteristics of 30th September 1993 Killari Earthquake Area, Maharashtra (India): - Journal of Geophysics, XXV (2 \& 3): 55-61.

KAYAL, J. R. (2000): Seismotectonic study of the recent SCR earthquake in central India. - Memoir Geological Survey of India, 55: 123-138.

Keller, E.A, \& Pinter, N. (1996): Active Tectonics Earthquakes, Uplift and Landscape. - Prentice Hall-Inc, 337 pp.

Kissel, C. \& LAJ, C. (1989): Palaeomagnetic Rotations and Continental Deformation. - 513 pp., The Netherlands (Kluwer).

McKenzie, D. \& Jackson, J. (1986): A block model of distributed deformation by faulting. - Journal of Geological Society of London, 143: 349-353.

Mishra, D.C., Tiwari, V.M., Gupta, S.B. \& RaO, Y.M.B.S. (1998): Anomalous mass distribution in the epicentral area of Latur earthquake, India. Current Science, 74: 469-472.

Mishra, S., Sonali, N., Rajaguru, S.N., Sushma D. \& Savita G. (2003): Fluvial response to late Quaternary climatic change: Case studies from Upland Western India. - Proc. Indian Natn. Sci. Acad. 69 (2): 185-200.

Mitchell, C., ¿ WidDowson, M. (1991): A geological map of southern Deccan traps, India and its structural implications. - Journal of Geological Society of London, 148: 495-505.

MuLLER, J.E. (1968): An introduction to hydraulic and topographic sinuosity indices. - Annals of Association of American Geography, 58: 371-385.
NAnson, G.C. \& Tooth, S. (1999): Palaeoenvironmental reconstruction in Arid Land - (Eds. A.K. Singhvi ש E. Derbyshire), Oxford and IBH Delhi, $175 \mathrm{pp}$.

Peshwa, V.V. \& Kale, V.S. (1997): Neotectonics of the Deccan Traps Province: Focus on the Kurduwadi Lineament. - Journal of Geophysics, 1: 77-86.

PowAR, K.B. (1993): Geomorphological evolution of Konkan Coastal belt and adjoining Sahyadri uplands with reference to Quaternary uplift. Current Science, 64 (11 \& 12): 793-796.

Rachna RaJ, Maurya, D.M. \& Chamyal, L.S. (1999): Tectonic Geomorphology of Mahi River basin Western India. - Journal of Geological Society of India, 54: 387-398.

RADHAKRISHNA, B.P. (1993): Neogene uplift and geomorphic rejuvenation of the Indian Peninsula. - Current Science, 64: 787-793.

RAJAgURU, S.N. \& KALE, V.S. (1985): Changes in the fluvial regime of Western Maharashtra upland rivers during Late Quaternary. - Journal of Geological Society of India, 26: 16-27.

RAJAGURU, S.N., KALE, V.S. \& BADAM, G.L. (1993): Quaternary fluvial systems in Upland Maharashtra. - Current Science, 64 (11 \& 12): 817-822.

RAJENDRAN, C.P. (1997): Deformational features in river bluffs at Ter, Osmanabad district, Maharashtra, evidence for an ancient earthquake. Current Science, 82: 750-755.

RajendRAN, C.P., RajendRAN, K. \& JoHn, B. (1996): The 1993 Killari (Latur) Central India Earthquake: An example of fault reactivation in the Precambrian crust. - Geology, 24: 651-654.

RAJENDRAN, C.P. \& RAJENDRAN, K. (1999): Geological investigations at Killari and Ter central India and implications for palaeoseismisity in the shield region. - Tectonophysics, 308: 67-81.

RajendRan, K. \& RajendRan, C. P. (1998): Characteristics of the 1997 Jabalpur earthquake and their bearing on its mechanism. Current Science, 74: 168-174.

RHEA, S. (1993): Geomorphic observations of rivers in the Oregaon coast range from a regional reconnaissance prospective. - Geomorphology, 6: $135-150$.

Schumm S.A. (1978): The fluvial system. - New York (Wiley)

Stuiver, M., \& Reimer, P.J. (1993): Extended ${ }^{14} \mathrm{C}$ database and revised CALIB radiocarbon calibration program. - Radiocarbon, 35: 215-230.

Srivastava, S.K., Dangwal ManoJ, Bhattachrya, A. and Reddy, P.R. (1997): Satellite data reveals pre-earthquake thermal anomalies in Killari area, Maharashtra. - Current Science, 72: 880-884.

SukHija B.S., B.V.Lakshmi, M.N. RaO, D.V. Reddy, P. Nagabhushanam, Syed Hussain ơ. Gupta H.K (2006): Widespread Geologic Evidence of a large Paleoseismic event near the Meizoseismal Area of the 1993 Latur Earthquake, Deccan Shield, India. - Journal of Indian Geophysical Union, 10(1): 1-14.

TIWARI, M.P. (1999): Quaternary Lithostratigraphic formations of Central Indian River Basins; their Correlation and Chronology. - Gondwana Geological Magazine, 4: 17-31.

TIWARI M.P. (2001): Quaternary Geology of Central India. - Geological Survey of India, 64: 625-635.

TiWARI, M.P. \& BHAI, H.Y. (1997a): Geomorphology of the alluvial fill of the Narmada valley. - Geological Survey of India, 46: 9-18.

TIWARI, M.P. \& BHAI, H.Y. (1997b): Quaternary stratigraphy of the Narmada valley. - Geological Survey of India, 46: 33-63.

TIWARI, M.P. \& BHAI, H.Y. (1998): Quaternary stratigraphy of the Purna valley. - Geological Survey of India, 128: 30-31.

Tiwari, M.P., Bhai, H.Y., Padhi, R.N. \& Bandopadhyay (1996): Geomorphology and Geology of the Purna valley. Symposium on Integrated approach to management of water and soil of Purna river basin with special reference to Salinity, 2-4 Feb. 1996, VRCE Nagpur.

Tiwari M.P., BHAi H.Y. \& VARAde A.M. (2010): Stratigraphy and Tephra beds of Purna Quaternary basin, Maharashtra, India. - Gondwana Geological Magazine, 12: 283-292.

VALDIYA, K.S. (1993): Latur Earthquake and 30 ${ }^{\text {th }}$ September, 1993: Implications and planning for hazard preparedness. - Current Science, 65(7): 515-517.

YADAVA, M. G. ¿ RAMESH, R. (1999): Speleothems-Useful proxies for past monsoon rainfall. - Journal of Scientific and Industrial Research, 58: $339-348$. 